\title{
Low energy compositions based on inorganic binders
}

\author{
V.V. Glukhovskyi (0000-0003-3917-174X), I.V. Glukhovskyi (0000-0003-3830-2891) \\ National Technical University of Ukraine "Igor Sikorsky Kyiv Polytechnic Institute”, aven. Peremogy, 37, Bldg. 21, \\ Kyiv, 03056, Ukraine \\ Tel.: +380672985775 \\ E-mail: lpchernyak@ukr.net
}

Article info: received 22.11.2019, revised 29.11.2019, accepted 20.12.2019

Glukhovskyi, V.V., Glukhovskyi, I.V. (2019) Low energy compositions based on inorganic binders 4(45), doi: 10.26909/ csl.4.2019.4

The results of scientific research in realization of energy-intensity cellular concrete production technology of normal condition hardening are shown. Physical-mechanical and thermophysical properties of cellular concretes, which are produced by this technology, are relevant to active normative documents. In this case the produced cellular concretes are characterized with strength increasing in time in compare to autoclave hardening cellular concretes and aerated concrete. The influence of the chemical activity of the fillers on the performance of the final product has been established.

According to the results of the performed researches it is established that the activity of the filler determines the kinetics of change in the time of the strength of the composition, which solidifies under normal conditions. When used as ground coal ash filler, the level of strength of porous concrete at the age of 28 days is at the level of strength of the composition with the addition of ground granulated slag (3,22 and 3,38 $\mathrm{MPa}$, respectively).

It is also found that, unlike autoclaved aerated concretes, the strength of aerated concretes of normal cement based on Portland cement increases over time both on binder without mineral additives and in the presence of ash, milled slag and quartz sand. The intensity of the process of gaining strength over time is determined by the activity of the mineral additive. When used as a mineral admixture of non-ground quartz sand, which, under normal curing conditions, does not interact with the curing of Portland cement, the strength of the porous concrete decreases with increasing amount of this additive in the composition. The intensity of the strength of these compositions at the age of 90 days, depending on the amount of additive, is $10-18 \%$.

The proposed technology for the production of cellular concrete based on Portland cement, curing under normal conditions, was implemented in industrial production. D700 concrete was selected as the base for production.

Key words: inorganic binders, cellular concrete, aerated concrete.

\section{Низькоенергоємні композиції на основі неорганічних в'яжучих}

\author{
В.В. Глуховський, І.В. Глуховський \\ Національний технічний університет України “Київський політехнічний інститут імені Ігоря Сікорського”, \\ Київ, Україна
}

Представлені результати науково-дослідних робіт з реалізації низькоенергоємної технології виробництва ніздрюватих бетонів, що твердіють у нормальних умовах. Фізико-механічні та теплофізичні характеристики бетонів, що виготовляються за розробленою технологією, відповідають вимогам чинних нормативних документів, при цьому ніздрюваті бетони характеризуються збільшенням міцності в часі на відміну від ніздрюватих бетонів автоклавного твердіння та пінобетонів. Встановлено вплив хімічної активності наповнювачів на експлуатаційні характеристики кінцевого продукту.

\section{Вступ}

Енергоємність галузі будівельних матеріалів є визначаючим показником ефективності готового продукту та обумовлює іiі кінцеву собівартість. Цей показник включає, як енергетичні витрати технології виробництва, так і енергоємність сировинних компонентів. Енергетичні витрати технологічного процесу 
істотно залежать від наявності в процесі виробництва таких технологічних операцій як сушка або тепловолога обробка виробів. Енергоємність виробництв, які в якості в'яжучого використовують портландцемент, визначається енергоємністю цього продукту.

За даними асоціації «Укрцемент», середні по галузі витрати палива та електричної енергії на виробництво портландцементу складають: паливо - 123,5 кг у. п. на тонну клінкеру (при сухому способі) та 226,2 кг у. п. (при вологому способі); електроенергія - 121,6 кВт.год на тонну цементу (при сухому способі) та 105,9 кВт·год (при вологому способі). У відповідності до вказаних показників загальна енергоємність виробництва портландцементу по галузі складає при сухому способі - 4900 МДж/т цементу, при вологому способі - 8200 МДж/т цементу.

Високі енергетичні витрати цементного виробництва обумовлюють сучасні тенденції, що направлені на зниження клінкерної складової цементів, які відображені в національних нормативних документах та дозволяють вводити до складу цементів до 80 мас. \% техногенних відходів інших виробництв. Але підприємствам виробникам портландцементу не завжди вигідно виробництво таких видів в'яжучих у зв'язку з неритмічністю роботи галузі.

В той же час, на ринку вже присутні тонкомелені техногенні багатотоннажні відходи, які можуть бути використані у технологіях виробництва будівельних виробів і використання яких дозволяє суттєво скоротити енергоємність готового продукту. До таких продуктів відносяться мелений гранульований шлак, зола виносу теплових електростанцій та мелена кам'яновугільна зола.

Метою науково-дослідних робіт, результати яких наведені у даній публікації, було розробка складів і технологій виробництва ніздрюватих бетонів, що твердіють в нормальних умовах на основі портландцементу та низькоенергоємних в'яжучих систем до складу яких включалися техногенні відходи, присутні на ринку.

\section{Матеріали та методи дослідження}

Введення до складу твердіючого цементного каменя наповнювачів або заповнювачів, що здійснюється 3 метою зниження витрати цементу, обумовлює необхідність врахування, при проектуванні складів таких композицій, процесів, які відбуваються в зоні контакту в'яжучого та наповнювача або заповнювача.

Відомо, що експлуатаційні характеристики композитів на основі неорганічних в'яжучих визначаються не тільки властивостями основних компонентів композиції, але і процесами міжфазної взаємодії в зоні їх контакту. За видом міжфазної взаємодії композиції можуть бути розділені на три класи. Це композиції, в яких міжфазна взаємодія відсутня, а міцність зони контакту визначається силами механічного зчеплення, композиції, в яких наповнювач і матриця утворюють тверді розчини без утворення хімічних сполук та композиції, в контактних зонах яких відбувається утворення нових хімічних сполук [1]. При цьому основні експлуатаційні властивості готового продукту визначаються не тільки міцністю зони контакту, але і залежать від товщини реакційної зони, яка у свою чергу визначається інтенсивністю процесів хімічної взаємодії основних компонентів композиції в зоні контакту.

Дослідження [2] залежності фізико-механічних характеристик композицій від реакційної здатності матеріалу матриці і наповнювача показали, що їх кінцевий рівень міцності істотно залежить як від умов формування структури, так і від реакційної здатності новоутворень твердіючої матриці і хімічної активності наповнювача, що використовується. При однакових фізико-механічних характеристиках наповнювача і матриці міцність композиції за відсутності хімічної взаємодії в зоні контакту не перевищувала 12 МПа. Використання в якості матриці в'яжучого, новоутворення якого здатні до утворення в зоні контакту нових хімічних сполук, дозволяє отримати композиції з рівнем міцності 40 - 50 МПа. Температурна інтенсифікація процесів хімічної взаємодії між наповнювачем та новоутвореннями матеріалу матриці дозволяє підвищити даний показник до $60 \mathrm{MПа,} \mathrm{а} \mathrm{використання} \mathrm{розчинного} \mathrm{наповнюва-}$ ча - до 75 МПа. Ці дані вказують на можливість зміни в широких межах основних властивостей композицій шляхом регулювання інтенсивності процесів хімічної взаємодії в зоні контакту.

Проте, у разі реалізації технології виробництва композицій, які твердіють в нормальних умовах, можливість регулювання інтенсивності процесів хімічної взаємодії в зоні контакту термічними методами стає неможливим. А для збільшення міцності контакту матриці і наповнювача (або заповнювача) можуть бути рекомендовані або метод підвищення механічної міцності зчеплення за рахунок підвищення міцності матеріалу матриці, або метод підвищення міцності зони контакту за рахунок використання хімічно активного наповнювача (або заповнювача).

На підставі вищевикладеного, а також $з$ урахуванням результатів аналізу відомих технічних рішень для заміни частини цементу в роботі були використані в якості наповнювачів зола суха кам'яновугільна 3 питомою поверхнею $2656 \mathrm{~cm}^{2} /$ г та шлак мелений доменний гранульований 3 питомою поверхнею $3159 \mathrm{~cm}^{2} / \Gamma$, а в якості заповнювача немелений кварцовий пісок з модулем крупності 1,43. 


\section{Результати та їх обговорення}

Експериментальний підбір робочих складів ніздрюватих бетонів із заміною частини портландцементу на золу і мелений доменний гранульований шлак, а так само при введенні до складу газобетону немеленого кварцового піску, здійснювався на основі методики, що була розроблена 3 метою удосконалення процесу розробки робочих складів з урахуванням реологічних характеристик суміші. Результати випробування підібраних складів наведені в таблиці 1.

Аналізом залежностей (рис. 1), що характеризують кінетику набору міцності ніздрюватим бетоном який виготовлений на основі базового складу (зразок 1) та з добавками в якості наповнювача золи (зразок 2), та меленого шлаку (зразок 3) встановлено, що характер кривої яка характеризує кінетику зміни міцності ніздрюватого бетону з добавкою золи відрізняється від аналогічних залежностей для базового складу та складу з добавкою шлаку.

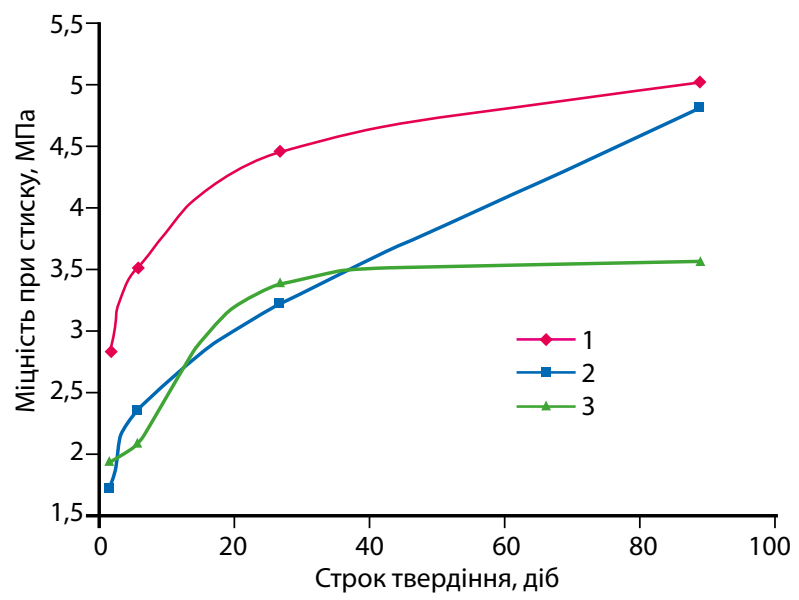

Рис. 1. Кінетика зміни міцності при стиску ніздрюватого бетону на основі базового складу (1), 3 добавкою золи (2) та з добавкою меленого шлаку (3) протягом 90 діб твердіння у нормальних умовах
Протягом 28 діб нормального твердіння рівень міцності ніздрюватого бетону з добавкою золи та меленого шлаку знаходився практично на однаковому рівні 3,22 та 3,38 МПа відповідно. Але при подальшому твердінні відмічається різке збільшення міцності ніздрюватого бетону з добавкою золи у віці 90 діб до рівня 4,81 МПа, тобто майже на $50 \%$, тоді як рівень міцності ніздрюватого бетону з добавкою меленого шлаку за той же період збільшився всього на 6 \%.

Аналогічна залежність, яка характеризує кінетику набору міцності матеріалу матриці (рис. 2) свідчить про те, що рівень міцності матеріалу матриці зразків з добавкою шлаку у віці 28 діб складає 40,9 МПа, тоді як аналогічний показник матеріалу матриці з добавкою золи характеризується значенням 27,7 МПа. При подальшому твердінні рівень міцності матеріалу матриці зразків 3 добавкою шлаку практично не змінюється і у віці 90 діб складає 43,3 МПа, а аналогічній показник для зразків з добавкою золи дорівнює $35,5 \mathrm{MПа,} \mathrm{тобто}$ збільшився на $28 \%$.

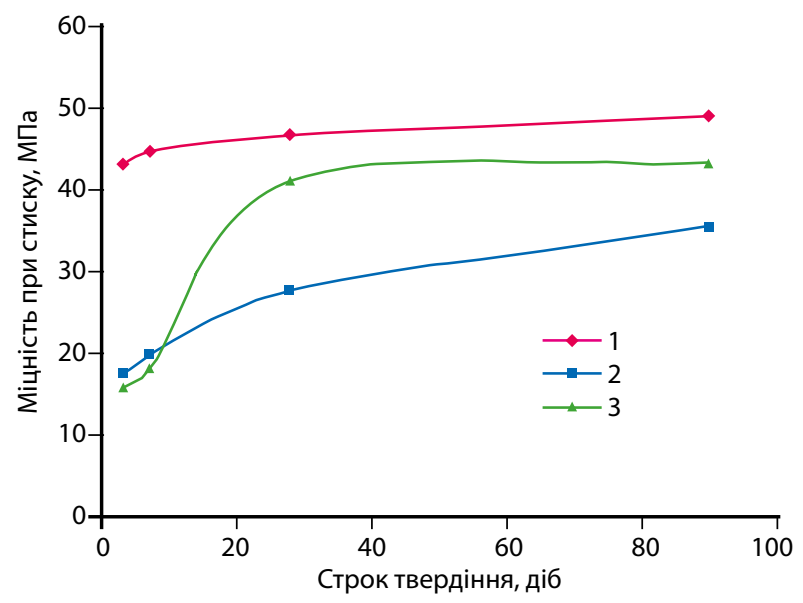

Рис. 2. Кінетика зміни міцності при стиску матеріалу матриці на основі базового складу (1), 3 добавкою золи (2) та з добавкою меленого шлаку (3) протягом 90 діб твердіння у нормальних умовах

Таблиця 1.

Фізико-механічні характеристики ніздрюватих бетонів на основі портландцементу з добавками золи, меленого доменного гранульованого шлаку та кварцового піску

\begin{tabular}{|c|c|c|c|c|c|c|c|c|}
\hline \multirow{2}{*}{ 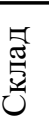 } & \multirow{2}{*}{ 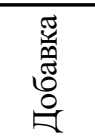 } & \multirow{2}{*}{$\begin{array}{c}\text { Кількість } \\
\text { добавки, мас. \% } \\
\text { від цементу }\end{array}$} & \multirow{2}{*}{ 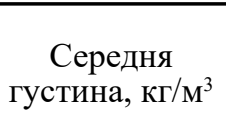 } & \multicolumn{5}{|c|}{ Міцність при стиску, МПа, у віці, діб } \\
\hline & & & & 3 & 7 & 28 & 90 & 360 \\
\hline 1 & - & 0 & 640 & 2,83 & 3,52 & 4,46 & 5,03 & 5,06 \\
\hline 2 & зола & 67 & 630 & 1,71 & 2,34 & 3,22 & 4,81 & 5,06 \\
\hline 3 & шлак & 100 & 630 & 1,92 & 2,09 & 3,38 & 3,58 & 3,84 \\
\hline 4 & пісок & 20 & 630 & 2,22 & 2,64 & 3,05 & 3,61 & 4,02 \\
\hline 5 & пісок & 30 & 640 & 2,05 & 2,29 & 2,93 & 3,31 & 3,88 \\
\hline 6 & пісок & 40 & 650 & 1,79 & 1,93 & 2,41 & 2,64 & 3,31 \\
\hline
\end{tabular}


3 метою визначення причин зазначеного протиріччя у роботі було виконано диференційно-термічний аналіз зразків матеріалу матриці базового складу та складів 3 добавками золи і меленого шлаку у віці 90 діб.

Аналіз наведених результатів диференційно-термічного аналізу (табл. 2) свідчить про те, що матеріал матриці зразків, які виготовлені на основі портландцементу характеризується наявністю трьох основних ендоефектів. Перший ендоефект у температурному інтервалі 20 - $200{ }^{\circ} \mathrm{C}$ відноситься до дегідратації алюмінатної фази та часткової втрати міжшарової води в продуктах гідратації; другий ендоефект в температурному інтервалі 500 - $580{ }^{\circ} \mathrm{C}$ відноситься до процесу дегідратації портландиту - $\mathrm{Ca}(\mathrm{OH})_{2}$ та характеризує кількість вказаного продукту у системі; третій ендоефект в температурному інтервалі $700-800^{\circ} \mathrm{C}$ характеризує наявність у продуктах гідратації гідросилікатів кальцію.

Наведені результати вказують на те, що в цементному камені матеріалу матриці 3 добавкою золи кількість алюмінатної фази (7,5 мас. \%) у порівнянні з базовим складом (5,5 мас. \%) збільшується, що є результатом взаємодії гідроксиду кальцію 3 золою. Про це також свідчить зменшення кількості гідроксиду кальцію у вказаному зразку (1,25 мас. \%) у порівнянні з базовим складом (1,75 мас. \%).

В разі використання в якості добавки меленого шлаку, кількість алюмінатної фазі (10,0 мас. \%) також перевищує аналогічний показник базового складу (5,5 мас. \%). Але таке збільшення алюмінатної складової не результат взаємодії продукту гідратації портландцементу зі шлаком, а гідратації самого шлаку, про що свідчить збільшення кількості портландиту у цьому зразку (3,0 мас. \%) у порівнянні з базовим складом (1,75 мас. \%).

Наведені результати вказують на те, що у разі використання в якості добавки золи, в процесі структуроутворення цементного каменю відбувається взаємодія золи з гідроксидом кальцію, який утворюється при гідратації портландцементу. В разі використання в якості добавки меленого шлаку, кількість гідратних новоутворень збільшується за рахунок гідратації шлаку.
Цей процес протікає в лужному середовищі, яке зумовлене присутністю у системі гідроксиду кальцію, але не забезпечує хімічної взаємодії добавки та продуктів іiі гідратації з новоутвореннями портландцементу.

Тобто на основі вказаних результатів диференційно-термічного аналізу може бути пояснено суттєве підвищення міцності ніздрюватого бетону 3 добавкою золи у віці 90 діб, тим, що у вказаній композиції саме в цей час протікають процеси хімічної взаємодії новоутворень цементного каменю та добавки. В разі відсутності такої хімічної взаємодії добавка наповнювача практично не впливає на міцність ніздрюватого бетону.

Про це свідчать залежності, що характеризують кінетику набору міцності ніздрюватим бетоном, який виготовленій з добавкою в якості заповнювача немеленого кварцового піску в кількості 20 мас. \% (зразок 2), 30 мас. \% (зразок 3) та 40 мас. \% (зразок 4) від кількості цементу (рис. 3). Міцність при

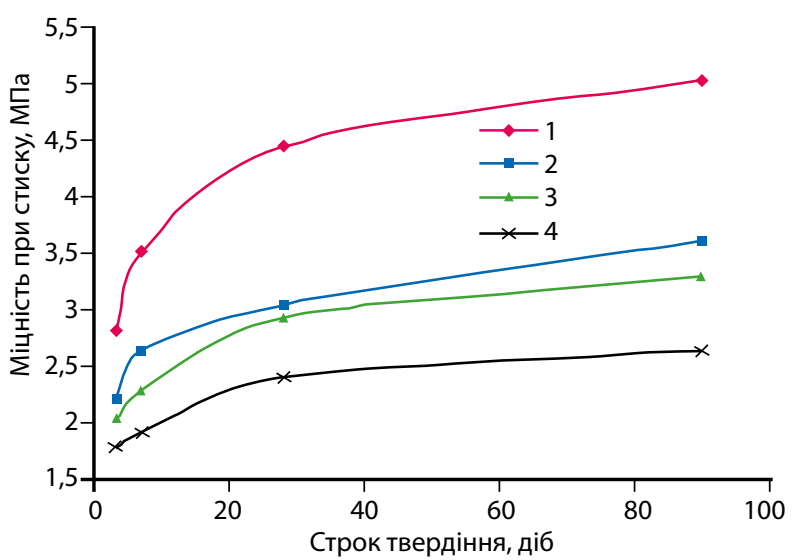

Рис. 3. Кінетика зміни міцності при стиску ніздрюватого бетону на основі базового складу (1)

та 3 добавкою немеленого кварцового піску у кількості 20 мас. \% (2), 30 мас. \% (3) та 40 мас. \% (4) від маси цементу

стиску таких композицій, зі збільшенням кількості заповнювача, знижується, а характер залежностей не змінюється з часом та відповідає характеру зміни у часі міцності матеріалу матриці (рис. 4).

Таблиця 2.

Значення втрат маси за результатами диференційно-термічного аналізу матеріалу матриці

\begin{tabular}{|c|c|c|c|c|c|}
\hline \multirow{2}{*}{ 预 } & \multirow{2}{*}{$\begin{array}{l}\text { Кількість добавки, } \\
\text { мас. \%, від цементу }\end{array}$} & \multicolumn{4}{|c|}{ Втрата маси, мас. \%, в температурному інтервалі } \\
\hline & & $20-200^{\circ} \mathrm{C}$ & $500-580^{\circ} \mathrm{C}$ & $700-800^{\circ} \mathrm{C}$ & в.П.П. \\
\hline 1 & без добавки & 5,5 & 1,75 & 5,75 & 20,0 \\
\hline 2 & зола -67 & $4,5(7,5)^{*}$ & $0,75(1,25)$ & $2,5(4,2)$ & 31,7 \\
\hline 3 & шлак - 100 & $5,0(10,0)$ & $1,5(3,0)$ & $2,25(4,5)$ & 40,0 \\
\hline
\end{tabular}

*примітка - в дужках наведені показники у перерахунку на 100 мас. \% цементу в складі композиції. 


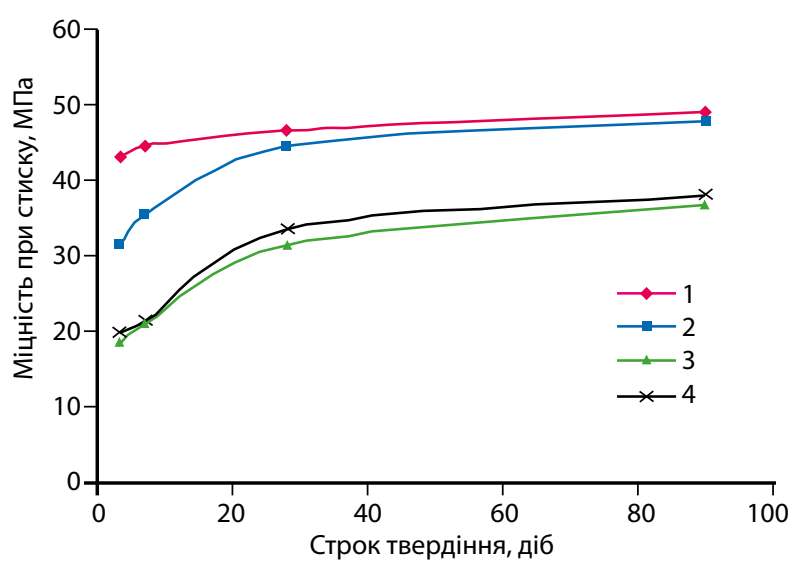

Рис. 4. Кінетика зміни міцності при стиску матеріалу матриці бетону на основі базового складу (1) та з добавкою немеленого кварцового піску у кількості 20 мас. \% (2), 30 мас. \% (3) та 40 мас. \% (4) від маси цементу

\section{Висновки}

За результатами виконаних досліджень встановлено, що активність наповнювача обумовлює кінетику зміни в часі міцності композиції, що твердіє у нормальних умовах. В разі використання в якості наповнювача меленої кам'яновугільної золи, рівень міцності ніздрюватого бетону у віці 28 діб знаходиться на рівні міцності композиції з добавкою меленого гранульованого шлаку (3,22 та 3,38 МПа відповідно). При подальшому твердінні, в період з 28 діб до 90 діб, міцність ніздрюватого бетону 3 добавкою золи збільшується до 4,8 МПа, тобто зростає майже на 50 \%, тоді як рівень міцності ніздрюватого бетону з добавкою меленого шлаку за той же період збільшився всього на 6 \%. При подальшому твердінні на протязі 360 діб міцність композиції при стиску зростає до 5,06 МПа та досягає рівня міцності композицій, які були виготовлені без використання мінеральних наповнювачів. Вказана залежність обумовлена наявністю процесів хімічної взаємодії наповнювача, що використовується 3 новоутвореннями твердіючого цементу.

Також встановлено, що на відміну від автоклавних ніздрюватих бетонів, міцність ніздрюватих бетонів нормального твердіння на основі портландцементу з часом зростає як на в'яжучому без мінеральних добавок, так і в присутності добавок золи, меленого шлаку та кварцового піску. Інтенсивність процесу набору міцності з часом визначається активністю мінеральної добавки. При використанні в якості мінеральної добавки немеленого кварцового піску, який в умовах нормального твердіння не взаємодіє з новоутвореннями портландцементу, що твердіє, міцність ніздрюватого бетону зменшується зі збільшенням кількості цієї добавки у складі суміші.
Інтенсивність набору міцності цих композицій у віці 90 діб, в залежності від кількості добавки, складає $10-18 \%$.

Максимальним значенням міцності при стиску у віці 28 діб характеризується ніздрюватий бетон без мінеральних добавок (4,5 МПа,). Аналогічна характеристика для ніздрюватого бетону 3 добавкою золи та меленого шлаку складає 3,2 та 3,4 МПа, а мінімальними значеннями міцності у віці 28 діб характеризуються бетони 3 добавкою немеленого піску 3,1, 2,9 та 2,4 МПа при кількості піску 20, 30 та 40 мас. \% відповідно. Проте, ніздрюваті бетони всіх названих складів за міцністю при стиску, перевищують значення, що регламентується діючим нормативним документом для неавтоклавних ніздрюватих бетонів.

Запропонована технологія виробництва ніздрюватих бетонів на основі портландцементу, що твердіють у нормальних умовах, була реалізована в умовах промислового виробництва. В якості базового складу для виробництва було обрано бетон Д700. За результатами випробування дослідно-промислової партії встановлено, що основні характеристики ніздрюватого бетону відповідають наступним параме-

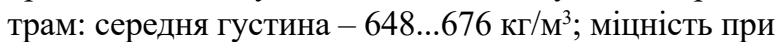
стиску - 4,27...4,58 МПа; сорбційна вологість при вологості повітря $97 \%$ - 11,30\%; втрата міцності після 50 циклів заморожування та відтаювання - 6,0 \%; коефіцієнт паропроникненості - 0,23 мг/(м·год·Па); теплопровідність ніздрюватого бетону у стандартних умовах $-0,18 \mathrm{BT} /(\mathrm{м} \cdot \mathrm{K})$, у розрахункових умовах експлуатації А - 0,21 Вт/(м·К), у розрахункових умовах експлуатації Б - 0,23 Вт/(м•К).

Високі фізико-механічні характеристики ніздрюватих бетонів, що були виготовлені за розробленою технологією, дозволили виробнику організувати виробництво стінових ніздрюватобетонних панелей розміром $3300 \times 1500 \times 500$ мм [3], які були використані при зведенні житлових малоповерхових будинків.

\section{References}

1. Композиционные материалы. Справочник. - К.: Наукова думка. - 1985. - 592 с.

2. Глуховський, В.В., Свідерський, В.А., Ященко, $O . M$, та ін. Композиційні матеріали на основі волокон 3 гірських порід та неорганічних в'яжучих. НАН України, Інститут проблем матеріалознавства ім. І.М. Францевича. - Київ. - 2006. - 140 с.

3. Свидерский, В.А., Дашкова, Т.С., Глуховский, B.В., Глуховский, И.В. Ячеистые бетоны естественного твердения. В кн.: Будівельні конструкції. Вип. 72. «Сучасні технології бетону». Зб. наук. праць. - К.: НДІБК. - 2009. - С. 328 - 334. 